\title{
Pengembangan Kemampuan Guru Di Pusat Kegiatan Belajar Masyarakat Daarus Sunnah Cibinong
}

\author{
Andri Rahadyan ${ }^{1 *}$, Halimatussa'diah ${ }^{2}$ \\ Universitas Indraprasta PGRI \\ 1e-mail: andri.rahadyan@gmail.com \\ 2e-mail: gbhock300679@gmail.com \\ *Corresponding Author
}

\begin{abstract}
ABSTRAK
Dalam era revolusi industri 4.0, masih banyak guru matematika saat ini yang belum memanfaatkan software yang ada pada teknologi komputer secara maksimal. Salah dua dari berbagai software yang ada adalah Cabri 3D dan GeoGebra. Cabri 3D dan GeoGebra adalah software yang dapat meningkatkan kualitas pembelajaran matematika di kelas dan membantu guru dalam mengonstruksi konsep matematika sehingga dapat membantu guru dalam kegiatan pembelajaran sehari-hari. Kegiatan pengabdian kepada masyarakat ini bertujuan untuk mengembangkan kemampuan para guru di Pusat Kegiatan Belajar Masyarakat SMP Daarus Sunnah Cibinong terhadap pengaplikasian software Cabri 3D dan GeoGebra sehingga mampu membuat media pembelajaran matematika yang dinamis dalam meningkatkan kualitas pembelajaran di kelas. Kegiatan ini menggunakan metode presentasi dan praktik untuk penggunaan software Cabri 3D dan GeoGebra. Hasil dari kegiatan ini adalah para guru memperoleh keterampilan untuk mengaplikasikan software Cabri 3D dan GeoGebra sehingga mampu membuat media pembelajaran matematika yang dinamis dan mampu mengeksplorasi konsep-konsep matematika sehingga mampu meningkatkan kualitas pembelajaran di kelas. GeoGebra memiliki fitur yang lebih banyak daripada Cabri 3D seperti dapat mengeksplorasi konsep aljabar, geometri 2D, geometri 3D, kalkulus, matriks, vektor, dan statistika. Cabri 3D hanya dapat digunakan untuk mengeksplorasi konsep geometri 2D dan geometri 3D.
\end{abstract}

Kata Kunci: Cabri 3D, Geogebra, Media, Pembelajaran, Dinamis

\begin{abstract}
In the era of the industrial revolution 4.0, there are many mathematics teachers who have not used technology in their classes. Two of the various software available are Cabri 3D and GeoGebra. Cabri 3D and GeoGebra are software that can improve the quality of learning mathematics in the classroom and help teachers in constructing mathematical concepts so that they can help teachers in daily learning activities. This community service activity aimed to develop the ability of teachers in The Center for Community Learning Activities in the Daarus Sunnah Cibinong Middle School to apply Cabri 3D and GeoGebra software so that they can create dynamic mathematics learning media. This activity used presentation methods and practices to use Cabri 3D and GeoGebra. The results of this activity were the teachers gain the skills to apply the Cabri 3D and GeoGebra so that they are able to create dynamic mathematics learning media and are able to explore mathematical concepts so as to improve the quality of learning in the classroom. GeoGebra has more features than Cabri 3D as it can explore the concepts of algebra, 2D geometry, 3D geometry, calculus, matrices, vectors, and statistics. Cabri $3 D$ can only be used to explore the concepts of $2 D$ geometry and $3 D$ geometry.
\end{abstract}

Keywords: Cabri 3D, Geogebra, Media, Learning, Dynamic 


\section{PENDAHULUAN}

Perkembangan teknologi di bidang pendidikan banyak memberi dampak positif terhadap perkembangan media pembelajaran. Beragam media pembelajaran yang berbasis teknologi informasi banyak digunakan di beberapa sekolah seperti laptop, proyektor, software pembelajaran dan video pembelajaran. Guru harus mempunyai kemampuan untuk mengikuti perkembangan teknologi tersebut. Media pembelajaran akan memberikan dampak positif jika para guru mampu mengoperasikan dan memanfaatkannya dengan baik dan benar. Manfaat teknologi informasi dalam kehidupan sehari-hari sangat banyak untuk berbagai bidang antara lain pendidikan, industri, internet, bisnis dan bidang lainnya.

Perkembangan informasi saat ini memunculkan harapan yang dapat meningkatkan daya minat anak-anak untuk belajar yang berawal pada usia dini. Pranasiwi, Iqbal, dan Suratno menjelaskan bahwa anak-anak harus mengenal teknologi tepat guna sejak dini (Pranasiwi et al., 2015). Bustomi menyatakan bahwa terdapat potensi besar dalam perkembangan teknologi multimedia, yaitu mengubah cara belajar seseorang, mendapatkan dan menyesuaikan informasi, mengembangkan teknik pembelajaran, dan sebagainya (Bustomi, 2010). Dalam peningkatan daya minat anak untuk belajar maka seorang guru harus mempunyai daya kreativitas dan inovasi dalam penyajian pembelajaran di kelas dengan menggunakan media pembelajaran yang berbasis teknologi. Teknologi informasi dan komunikasi, khususnya komputer, dewasa ini memiliki peran yang semakin besar dalam proses pendidikan. Komputer mempunyai peran sentral dalam memajukan kualitas pendidikan.

Berbagai negara melakukan pembaruan dalam proses pembelajaran dengan memanfaatkan teknologi. Perubahan signifikan yang terjadi adalah pemanfaatan komputer untuk mengeksplorasi apa yang sebelumnya tidak mungkin dilakukan dalam proses pembelajaran. Kualitas pembelajaran dapat meningkat dengan menggunakan program komputer yang dirancang dengan baik sehingga menghasilkan media pembelajaran yang sangat eksploratif.

Bagaimana dengan pembelajaran matematika di Pusat Kegiatan Belajar Masyarakat (PKBM) SMP Quran Daarus Sunnah Cibinong? Pemanfaatan komputer dalam pembelajaran matematika masih sangat minim. Berdasarkan diskusi dengan Kepala PKBM SMP Quran Daarus Sunnah Cibinong mengenai pemanfaatan teknologi dalam pembelajaran matematika, diperoleh data bahwa pemanfaatan komputer masih sangat terbatas dalam pembelajaran yaitu hanya penggunaan PowerPoint. Penggunaan teknologi pun masih sangat minim, khususnya dalam pembelajaran matematika. Para guru berpendapat bahwa pembelajaran matematika menjadi kaku dan siswa tidak mengetahui proses dalam menghasilkan konten yang ditampilkan dalam PowerPoint dibandingkan dengan menggunakan papan tulis dan spidol. Guru tidak mampu 
melakukan eksplorasi dalam pembelajaran konsep aljabar atau geometri yang memerlukan ilustrasi grafik apabila hanya menggunakan spidol dan papan tulis. Ilustrasi grafik pada papan tulis tidak bersifat dinamis sehingga siswa tidak dapat melakukan eksplorasi terhadap konsep aljabar maupun geometri yang sedang dipelajari. Dengan bantuan teknologi komputer, guru dan siswa mampu melakukan eksplorasi dalam pembelajaran karena ilustrasi grafik yang ditampilkan bersifat dinamis sehingga parameter-parameter yang perlu dipahami dapat dilihat perubahannya secara menyeluruh. Dengan demikian, hubungan antara persamaan matematika dan grafiknya sangat jelas terlihat. Namun sayangnya, banyak guru yang tidak mempunyai kemampuan membuat ilustrasi grafik dinamis dengan teknologi komputer untuk dimanfaatkan sebagai bahan ajar, lembar kerja siswa, maupun alat evaluasi hasil belajar yang baik dan benar bagi siswa.

Berdasarkan hal di atas, perlu suatu solusi yang dapat memecahkan permasalahan tersebut. GeoGebra dan Cabri 3D adalah salah dua dari berbagai program aplikasi komputer yang dapat dimanfaatkan untuk mengatasi permasalahan tersebut. Media pembelajaran yang dinamis merupakan salah satu cara untuk memberikan konsep materi kepada siswa secara menyeluruh. Media pembelajaran digunakan untuk mengurangi pembelajaran dengan metode ceramah. Melalui media pembelajaran, guru dapat berkreasi dan berinovasi dalam menyajikan materi sehingga materi yang disampaikan menarik dan membuat siswa antusias. Selain itu, media pembelajaran yang dinamis dapat digunakan untuk memotivasi siswa dalam belajar matematika. Accascina dan Rogora juga menyatakan hal yang senada bahwa siswa dan guru dapat mempelajari konsep geometri menjadi lebih mudah dan menarik dan dapat mengatasi kesulitan-kesulitan yang dialami sebelumnya dengan menggunakan software Cabri 3D (Accascina \& Rogora, 2006). Pada materi geometri bangun datar dan bangun ruang, guru dapat menggunakan software Cabri 3D sebagai media pembelajaran yang dinamis.

Software Cabri 3D didesain untuk membantu guru dalam mengonstruksi bangun datar maupun bangun ruang sehingga guru tidak perlu menggunakan penggaris, spidol, dan papan tulis untuk memvisualisasi konsep geometri tersebut. Mengonstruksi bangun datar maupun ruang dengan Cabri 3D dapat membantu guru mengefektifkan jam pelajaran untuk menyajikan pembelajaran matematika yang menarik, variatif dan efisien waktu. Selain itu, guru dapat membantu siswa dalam memvisualisasi bangun ruang yang dipelajari melalui Cabri 3D. Siswa tidak perlu membayangkan bagaimana bentuk dari limas segi empat, prisma segitiga dan sebagainya karena guru sudah mengonstruksi bangun tersebut dalam lembar kerja Cabri 3D. Hal tersebut sejalan dengan pendapat Anthony dan Walshaw yang menyatakan bahwa Cabri 3D mempunyai dasar yang kuat dalam membantu proses pembelajaran matematika khususnya geometri karena dapat memvisualisasi konsep geometri (Anthony \& Walshaw, 2009). Oleh karena 
itu, tujuan pembelajaran diharapkan dapat dicapai secara maksimal.

Software Cabri 3D berguna untuk mengonstruksi bangun datar, bangun ruang, menghitung panjang segmen, keliling, volume dan luas bangun serta mengukur sudut. Selain itu, tampilan dari software ini cukup menarik karena ada fitur warna untuk memberi efek warna pada bangun. Hal yang sangat menarik dari software ini, bangun ruang yang sudah dikonstruksi dapat dibuka sehingga siswa dapat melihat bagaimana bentuk dari jaring-jaring bangun ruang. Dengan demikian, guru dapat berkreasi dengan maksimal menggunakan software Cabri 3D ini dalam menyajikan materi bangun ruang.

Berdasarkan hasil penelitian atau pengabdian sebelumnya, Cabri 3D mampu meningkatkan minat dan hasil belajar matematika siswa pada materi bangun ruang (Maulana et al., 2017). Cabri 3D juga memiliki pengaruh terhadap hasil belajar dan motivasi siswa (Akhirni \& Mahmudi, 2015). Cabri 3D juga dapat meningkatkan kemampuan visualisasi spasial siswa (Adirakasiwi \& Warmi, 2018). Cabri 3D juga dapat digunakan untuk mengonstruksi bangun ruang, membuat media visual dan bahan ajar tentang bangun ruang (Hikmah \& Selvia, 2019). Cabri 3D juga membantu siswa dalam memahami konsep luas permukaan dan volume limas dengan lebih mudah (Kristin et al., 2013).

Markus Hohenwarter, dkk mengembangkan software yang dinamis dan konstruktif untuk pembelajaran khususnya matematika yang dinamakan GeoGebra (Hohenwarter et al., 2008). GeoGebra merupakan freeware dan dapat dijalankan pada berbagai jenis sistem operasi. GeoGebra bisa dimanfaatkan untuk membuat konsep-konsep matematika menjadi dinamik.

GeoGebra dapat mengonstruksi dan mengeksplorasi konsep geometri atau grafik dari suatu fungsi secara dinamis sehingga siswa mampu menyimpulkan suatu konsep beserta koneksi matematis dari konsep-konsep tersebut. GeoGebra mempunyai beberapa tampilan yaitu tampilan analitik untuk konsep aljabar, tampilan grafis untuk visualisasi, dan tampilan numerik. Matematika sebaiknya dipelajari dengan menggunakan paling sedikit tiga pendekatan, yaitu pendekatan analitik, visual, dan numerik. GeoGebra mampu mengakomodasi ketiga pendekatan tersebut dengan sangat baik. GeoGebra telah memperoleh sekitar 12 penghargaan internasional mulai tahun 2002 hingga 2010 yang membuat GeoGebra sebagai software pendidikan terbaik.

Berdasarkan hasil penelitian atau pengabdian sebelumnya, GeoGebra mampu membuat siswa lebih aktif dan berpartisipasi dalam pembelajaran sehingga pembelajaran menjadi bermakna (Ekawati, 2016; Widyastuti \& Nurhamida, 2017). GeoGebra juga dapat mendukung pembelajaran matematika menjadi lebih efektif (Novianggraeni \& Siswono, 2017). GeoGebra juga dapat menyediakan cara cepat dan mudah untuk membangun aplikasi yang sekali jadi untuk situasi pemecahan masalah matematis yang khusus (Fisher, 2017). GeoGebra juga memungkinkan siswa 
meningkatkan daya kreativitasnya karena siswa dapat membuat sendiri penyelesaian permasalahan sesuai dengan keinginan (Ekawati, 2016). GeoGebra juga dapat dijadikan sebagai media pembelajaran matematika yang mampu mendemonstrasikan atau memvisualisasikan berbagai konsep matematika serta sebagai alat bantu untuk mengonstruksi berbagai konsep matematika (Mahmudi, 2011). GeoGebra juga dapat meningkatkan kemampuan representasi matematis siswa (Oktaria et al., 2016).

Berdasarkan uraian di atas, maka kami menawarkan solusi berupa kegiatan pengabdian kepada masyarakat, khususnya kepada para guru yang ada di PKBM SMP Daarus Sunnah Cibinong. Tujuannya tak lain adalah untuk mempertanggungjawabkan ilmu yang kami miliki dengan jalan ikut serta dalam menciptakan generasi-generasi yang cerdas dalam berteknologi di masa depan. Kami bermaksud memberikan pelatihan keterampilan bagi guru dalam menggunakan software Cabri 3D dan GeoGebra dalam meningkatkan kualitas pembelajaran matematika di kelas.

\section{BAHAN DAN METODE}

Kegiatan pengabdian masyarakat ini dilakukan selama tiga bulan dari pengajuan proposal hingga pelaksanaan. Tahap persiapan, tim mengadakan observasi terhadap calon mitra kegiatan, wawancara dengan kepala PKBM SMP Daarus Sunnah Cibinong, mengurus berkas administrasi perizinan yang diperlukan untuk pelaksanaan kegiatan ini, dan menyiapkan proposal serta modul yang berisi materi yang akan diberikan kepada peserta kegiatan ini. Pelaksanaan pelatihan ini sendiri menggunakan dua jenis metode, yaitu presentasi dan praktik. Pelaksanaan kegiatan pengabdian kepada masyarakat di PKBM SMP Daarus Sunnah Cibinong dilakukan dalam dua sesi di sekolah. Pertemuan tersebut dimulai dengan presentasi tentang Cabri 3D. Pertemuan ini diawali dengan penjelasan tentang Pengenalan dan aturan dasar penggunaan Cabri 3D. Setelah itu, pemateri melanjutkan dengan penjelasan mengenai pengenalan tools dari Cabri 3D, cara membuat kubus dengan langsung dipraktikkan bersama, cara membuat balok, di lanjutkan dengan membuat limas dan prisma sampai selesai.

Kegiatan ini kemudian dilanjutkan dengan praktik menjalankan software GeoGebra. Seluruh anggota tim, kami juga mengikutsertakan dua mahasiswa Informatika untuk belajar dan membantu para guru yang membutuhkan bantuan dalam proses pengaplikasian software tersebut. Tujuan dari praktik ini adalah untuk mengetahui sejauh mana para guru menguasai keterampilan dalam menggunakan aplikasi Cabri 3D. Sesi kedua adalah mempraktikkan aplikasi GeoGebra yang di awali dengan pengenalan sejarah dan anatomi dari GeoGebra, di lanjutkan dengan pengenalan tampilan-tampilan dasar, pembuktian luas segitiga, jaring-jaring kubus-limas-prisma sampai selesai. 


\section{HASIL DAN PEMBAHASAN}

Hasil yang ingin dicapai kegiatan ini adalah para guru di PKBM SMP Daarus Sunnah Cibinong memperoleh keterampilan yang dapat digunakan untuk mengaplikasikan Cabri 3D dan GeoGebra dalam proses peningkatan kualitas belajar mengajar pada siswa. Dengan kata lain, hasil dari kegiatan pelatihan ini adalah para guru dapat meningkatkan kemampuan mereka dalam memanfaatkan aplikasi Cabri 3D dan GeoGebra dalam pembelajaran kelas siswa. Kemudian, dengan keterampilan tersebut para guru diharapkan mampu meningkatkan kinerja mereka.

Hasil dari kegiatan ini juga dapat dilihat pada materi dalam bentuk modul yang nantinya akan membekali pengajar di PKBM SMP Daarus Sunnah Cibinong untuk menjalankan proses belajar mengajar khususnya pada mata pelajaran matematika dan semisalnya dengan menggunakan aplikasi Cabri 3D dan GeoGebra.

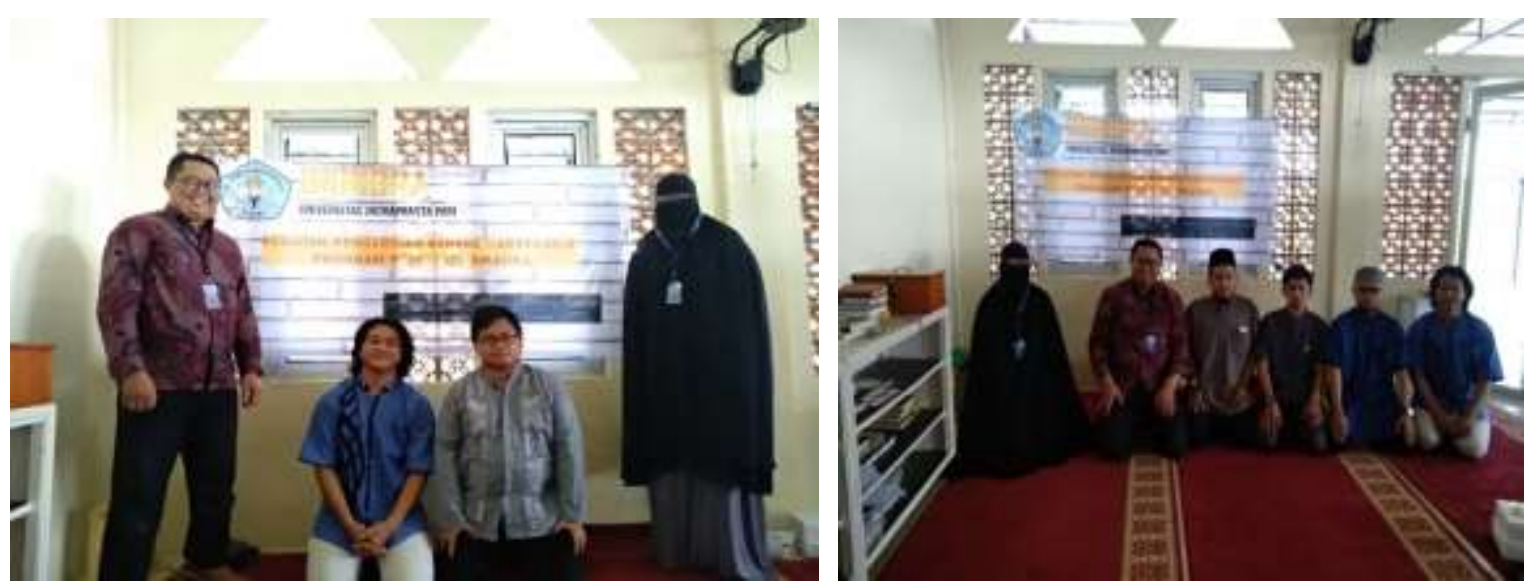

Gambar 1. Tim Pelaksana Pengabdian kepada Masyarakat dan Peserta
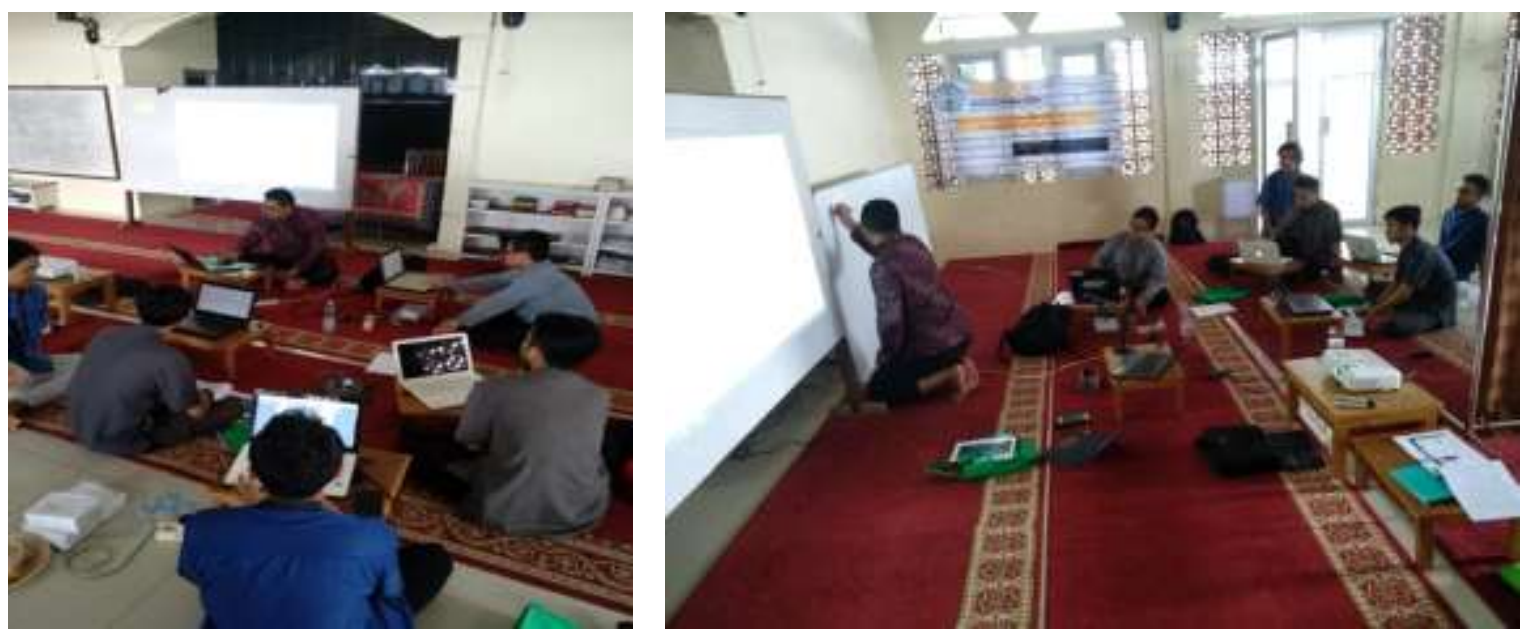

Gambar 2. Proses Kegiatan Pengabdian kepada Masyarakat

Gambar 1. memperlihatkan tim pelaksana dan peserta kegiatan pengabdian kepada masyarakat di PKBM SMP Daarus Sunnah Cibinong. Gambar 2. memperlihatkan situasi dalam proses pelaksanaan kegiatan pengabdian kepada masyarakat ini. Peserta terlihat cukup antusia selama pelaksanaan kegiatan ini. 


\section{Software Cabri 3D}

Teknologi Cabri lahir pada tahun 1985 di laboratorium penelitian Centre National de la Recherche Scientifique Perancis dan Universitas Joseph Fourier di Grenoble. Pada awal target utama proyek itu adalah untuk membuat geometri dua dimensi lebih mudah dipelajari dan lebih menyenangkan untuk diajarkan. Belakangan filosofi Cabri dibawa ke dunia 3D. Cabri 3D diperlihatkan pertama kali selama konferensi CABRIWORLD di Roma pada bulan September 2004 (Rososzczuk, 2015). Berikut ini adalah tampilan beranda dan daftar fitur software Cabri 3D.

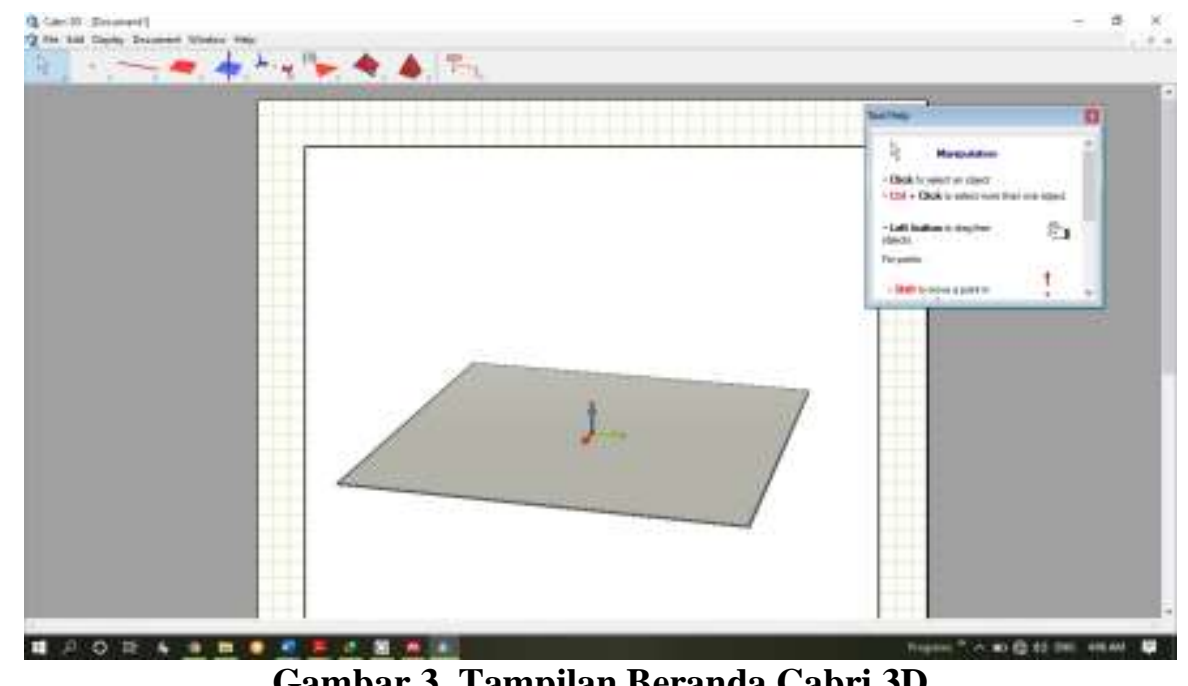

Gambar 3. Tampilan Beranda Cabri 3D

Tabel 1. Daftar Fitur dalam Software Cabri 3D

\section{Manipulation}

\section{Manipulation}

Digunakan untuk menormalkan fungsi kursor.

\begin{tabular}{ll}
\hline Points & $\begin{array}{l}\text { Redefinition } \\
\text { Digunakan untuk mendefenisikan titik tertentu pada base } \\
\text { plane. }\end{array}$ \\
\hline & $\begin{array}{l}\text { Point / Titik } \\
\text { Digunakan ketika akan membuat titik pada bidang VP atau } \\
\mathrm{NVP}\end{array}$ \\
\hline & $\begin{array}{l}\text { Intersection Point(s) / Titik Potong / } \\
\text { Digunakan ketika akan membuat sebuah titik potong atau } \\
\text { perpotongan antara dua garis, garis dengan bidang, bidang } \\
\text { dengan bidang, dan lain-lain. }\end{array}$ \\
\hline
\end{tabular}

\section{Curves (Kurva)}

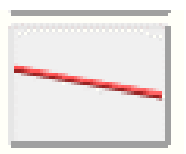

\section{Line / Garis}

Digunakan untuk membuat sebuah garis baik melalui dua titik atau garis yang dibentuk oleh perpotongan dua bidang. 


\begin{tabular}{|c|c|}
\hline & Ray / Sinar \\
\hline & $\begin{array}{l}\text { Digunakan untuk membuat sinar yang melalui dua titik, } \\
\text { dimana titik pertama merupakan titik awal sinar tersebut. }\end{array}$ \\
\hline & Segment / Ruas Garis \\
\hline & $\begin{array}{l}\text { Digunakan untuk membuat ruas garis dari dua titik yang } \\
\text { diketahui. }\end{array}$ \\
\hline & Vektor / Vektor Garis \\
\hline & $\begin{array}{l}\text { Digunakan untuk membuat sebuah vektor garis yang } \\
\text { didefinisikan oleh dua buah titik, dimana titik pertama } \\
\text { merupakan titik awal vektor tersebut. }\end{array}$ \\
\hline & Circle / Lingkaran \\
\hline & $\begin{array}{l}\text { Digunakan untuk membuat sebuah lingkaran yang } \\
\text { didefinisikan oleh dua titik (pusat dan jari-jari) pada bidang } \\
\text { datar. }\end{array}$ \\
\hline & Arc / Busur Lingkaran \\
\hline & $\begin{array}{l}\text { Digunakan untuk membuat busur lingkaran dan lingkaran } \\
\text { itu sendiri dengan mendefinisikan } 3 \text { titik tertentu. }\end{array}$ \\
\hline & Conic \\
\hline & $\begin{array}{l}\text { Digunakan untuk membuat Conic yang melalui } 5 \text { titik yang } \\
\text { sebidang. }\end{array}$ \\
\hline & Intersection Curve \\
\hline & $\begin{array}{l}\text { Digunakan ketika akan membuat garis dari perpotongan } \\
\text { antara dua bidang, membuat conic dari perpotongan antara } \\
\text { bidang datar dengan kerucut atau tabung, dan membuat } \\
\text { lingkaran dari perpotongan antara dua bola atau bidang datar } \\
\text { dengan bola. }\end{array}$ \\
\hline
\end{tabular}

\begin{tabular}{|c|c|}
\hline \multicolumn{2}{|c|}{ Surface / Permukaan } \\
\hline & Bidang Datar \\
\hline & $\begin{array}{l}\text { Sebuah bidang dapat dibentuk dengan beberapa cara yaitu, } \\
\text { - Melalui tiga titik tertentu (usahakan titik tidak } \\
\text { berada di base plane) } \\
\text { - Melalui dua garis yang sebidang. } \\
\text { - Melalui sebuah garis dan titik } \\
\text { - Didefinisikan dari sebuah segitiga atau poligon }\end{array}$ \\
\hline \multicolumn{2}{|r|}{ Half-Plane / } \\
\hline & $\begin{array}{l}\text { Half-Plane dapat dibentuk dengan cara: } \\
\text { - Dibatasi oleh sebuah garis dan memotong sebuah } \\
\text { titik } \\
\text { - Dibatas oleh } 3 \text { titik, dimana dua titik pertama } \\
\text { mendefinisikan sebuah garis dan memotong titik } \\
\text { ketiga }\end{array}$ \\
\hline
\end{tabular}




\begin{tabular}{ll}
\hline & $\begin{array}{l}\text { Sector } \\
\text { Untuk membuat sector bisa dilakukan dengan } \\
\text { mendefinisikan sebuah titik awal dan dua titik sebagai titik } \\
\text { yang lain. }\end{array}$ \\
\hline $\begin{array}{l}\text { Triangle } \\
\text { Untuk membuat sebuah segitiga bisa dilakukan dengan cara } \\
\text { mendefinisikan tiga buah titik tertentu. }\end{array}$ \\
\hline $\begin{array}{l}\text { Polygon } \\
\text { Untuk membuat sebuah polygon bisa dilakukan dengan cara } \\
\text { mendefinisikan tiga buah titik atau lebih dan untuk } \\
\text { menyelesaikannya dengan melakukan double-click pada } \\
\text { titik terakhir. }\end{array}$ \\
\hline $\mathrm{cm}$
\end{tabular}

Gambar 3. menunjukkan tampilan beranda software Cabri 3D yang memiliki beberapa fitur dalam Cabri 3D. Tabel 1. menjelaskan fitur-fitur yang terdapat dalam software Cabri 3D.

Cabri 3D digunakan hanya untuk mengeksplorasi konsep geometri baik 2D atau 3D. Berikut ini diberikan contoh aplikasi software Cabri 3D dalam mengeksplorasi salah satu bangun datar yaitu membuat kubus, membuat kerangka kubus, membuat jaring-jaring kubus, membuat diagonal bidang, membuat diagonal ruang, membuat bidang diagonal, menentukan panjang rusuk 
kubus, menentukan luas permukaan kubus, menentukan volume kubus, dan menentukan sudut dalam kubus.
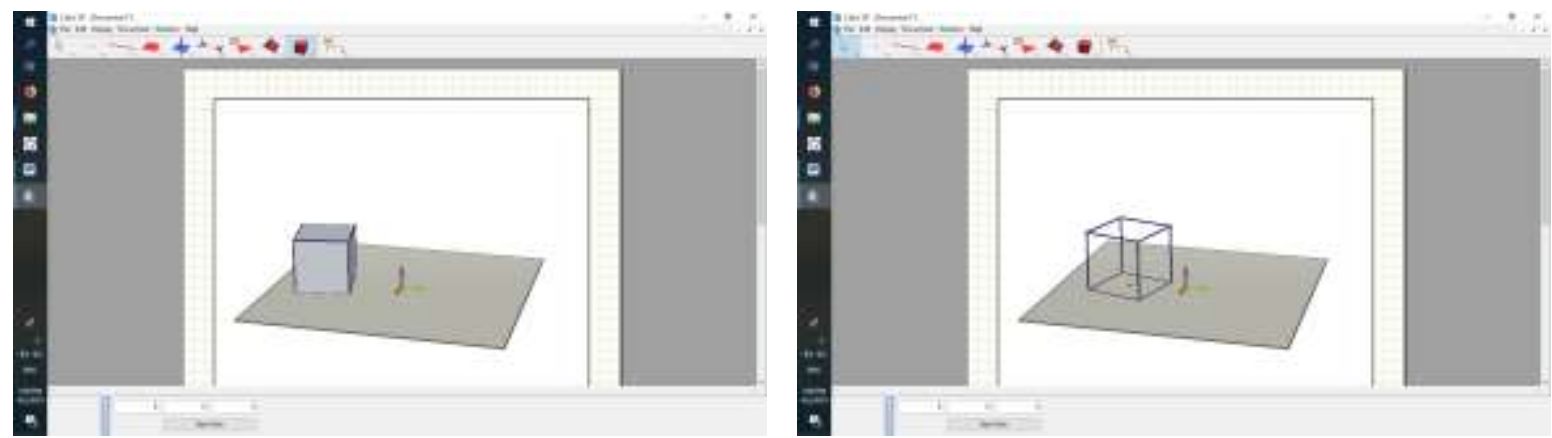

Gambar 4. Kubus dan Kerangka Kubus
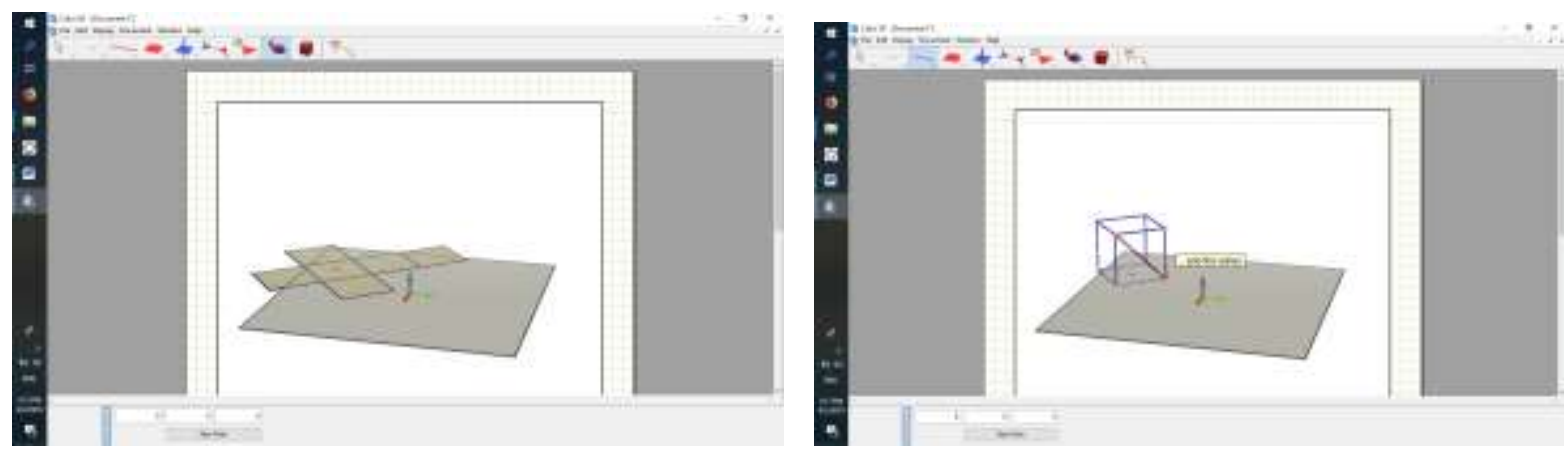

Gambar 5. Jaring-Jaring Kubus dan Diagonal Bidang

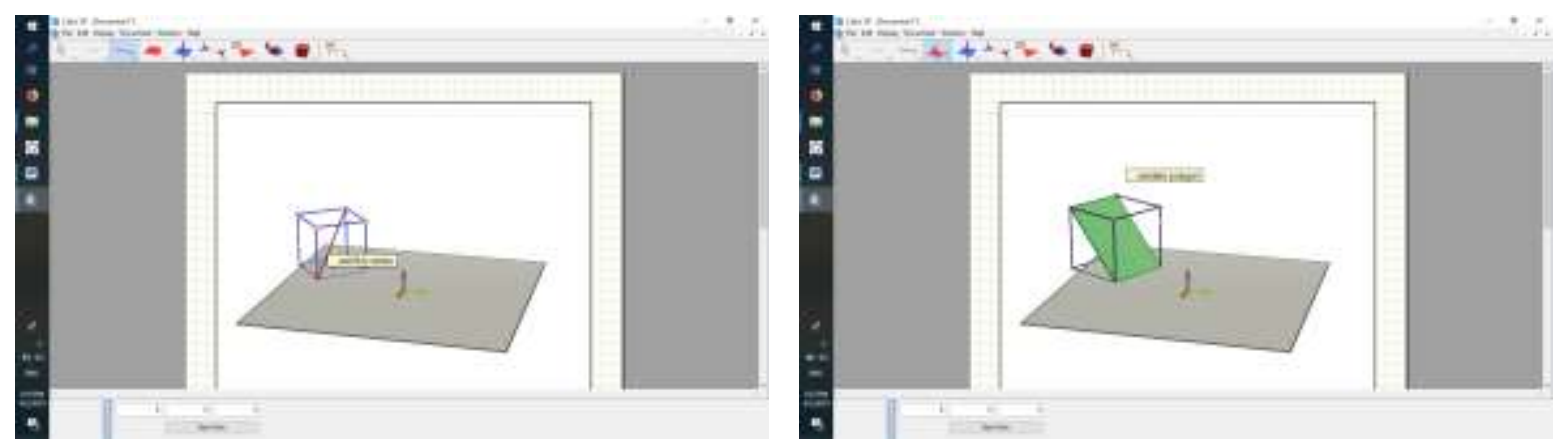

Gambar 6. Diagonal Ruang dan Bidang Diagonal
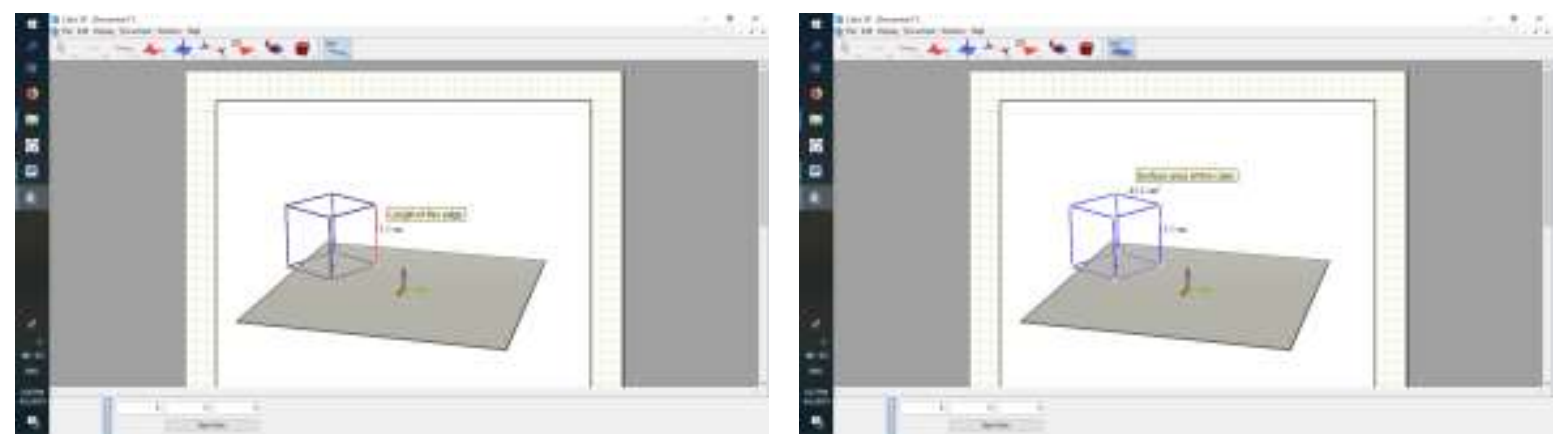

Gambar 7. Panjang Rusuk Kubus dan Luas Permukaan Kubus 


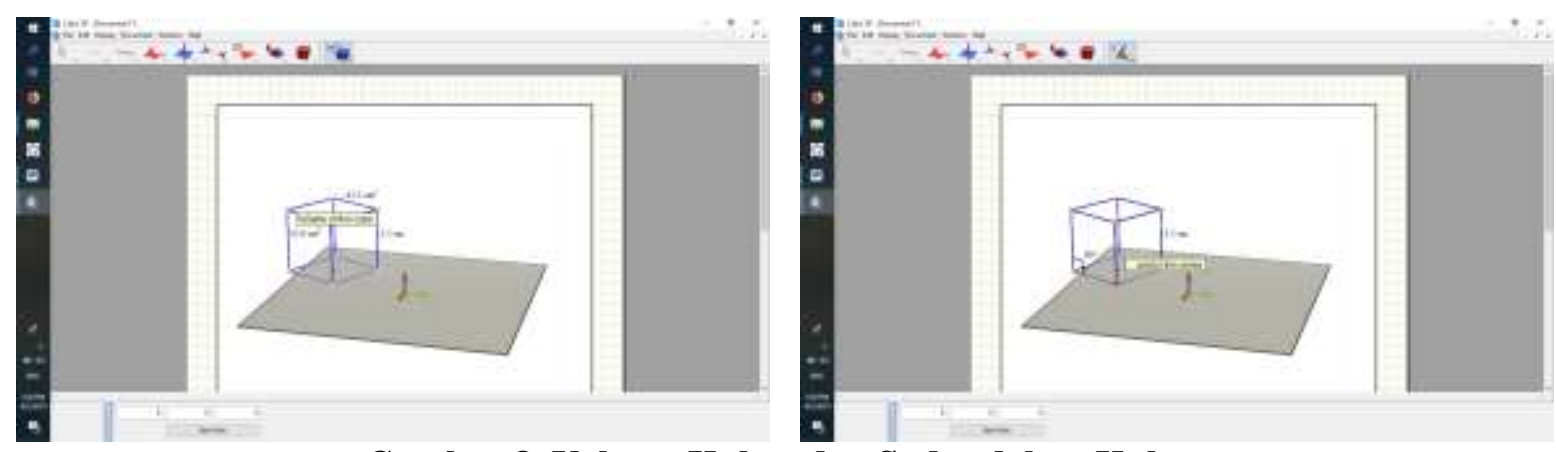

Gambar 8. Volume Kubus dan Sudut dalam Kubus

Gambar 4-8 menunjukkan bangun ruang kubus beserta karakteristiknya antara lain kerangka, jaring-jaring, diagonal bidang, diagonal ruang, bidang diagonal, panjang rusuk, luas permukaan, volume, dan sudut dalam kubus.

\section{Software GeoGebra}

Pada tahun 2001, seorang ahli matematika dan komputer Markus Hohenwarter menciptakan sebuah perangkat lunak yaitu GeoGebra. Dia menggabungkan konsep geometri, aljabar, dan kalkulus dalam satu lingkungan yang dinamis. GeoGebra adalah program perangkat lunak matematika dinamis yang bersifat open-source dan dibuat oleh Markus Hohenwarter untuk proyek tesis masternya di Universitas Salzburg, Austria. Berikut ini adalah tampilan beranda software GeoGebra.

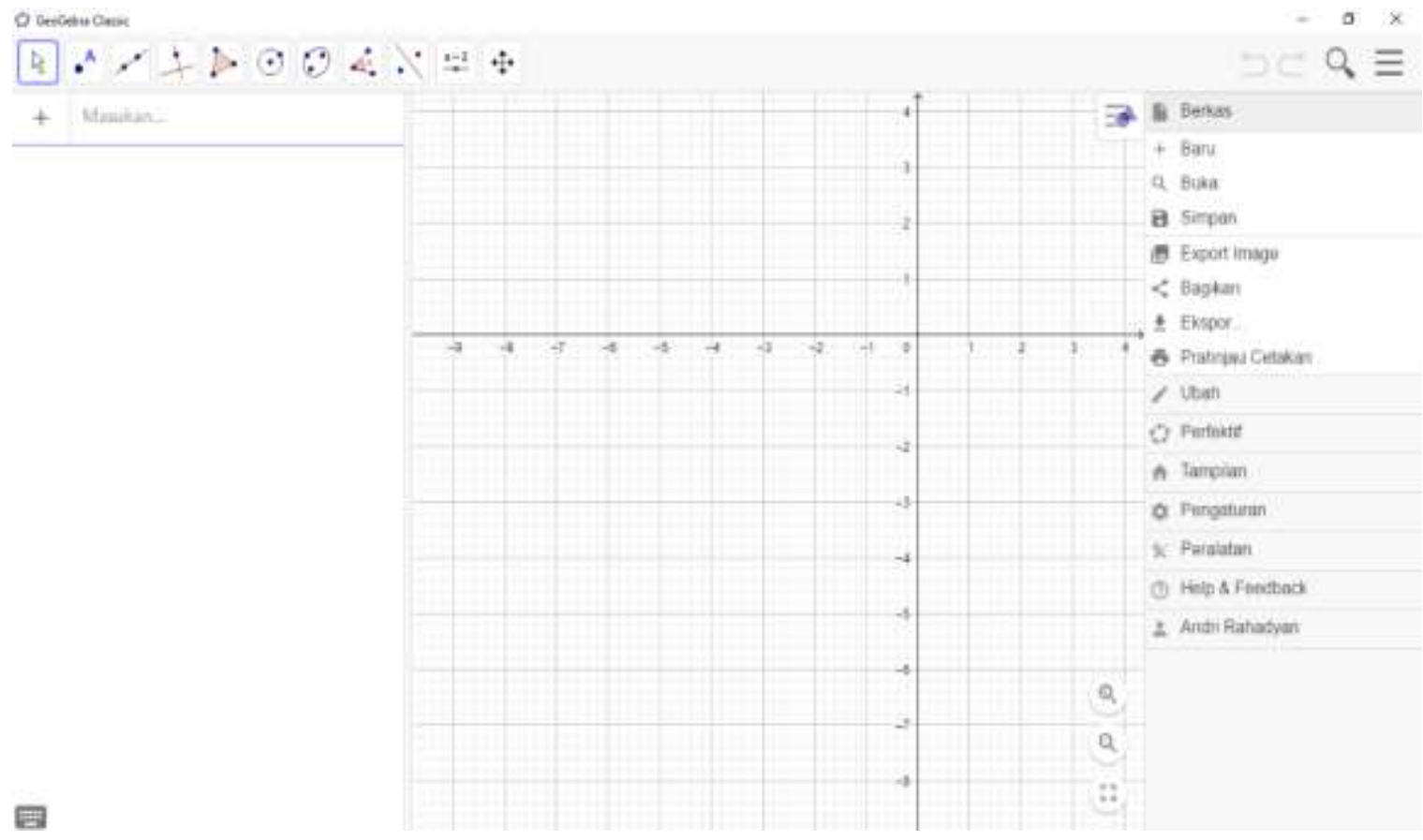

Gambar 9. Tampilan Beranda GeoGebra 
Gambar 9. menunjukkan tampilan beranda software GeoGebra beserta fitur-fitur yang di dalamnya. Berikut ini adalah beberapa contoh penerapan program GeoGebra antara lain mengkreasikan grafik fungsi linier, fungsi kuadrat, fungsi sinus, fungsi tangent, dan bangun ruang.

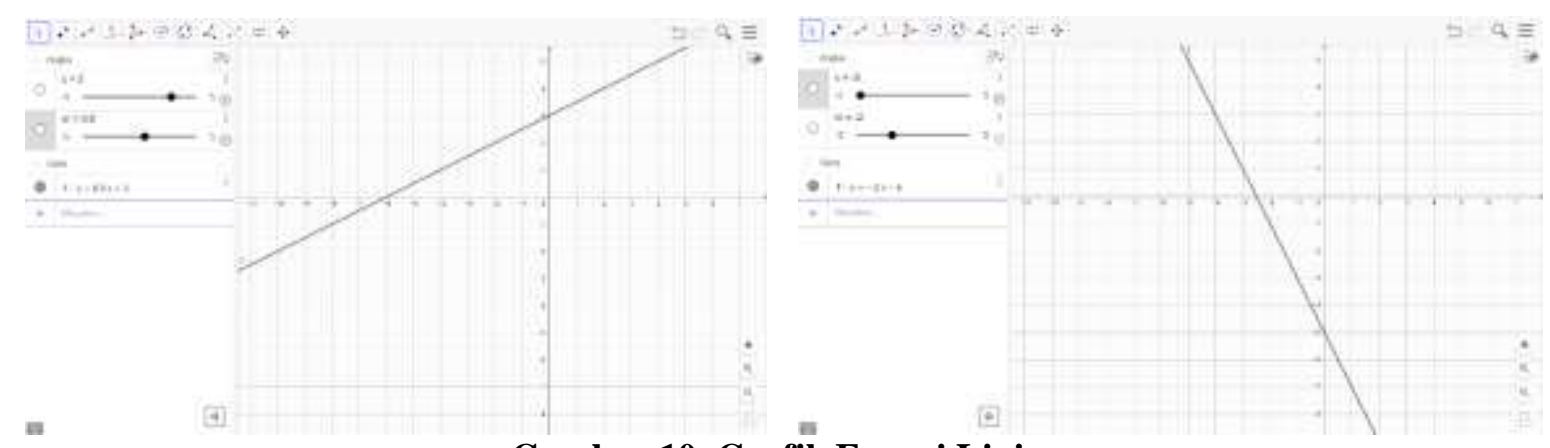

Gambar 10. Grafik Fungsi Linier

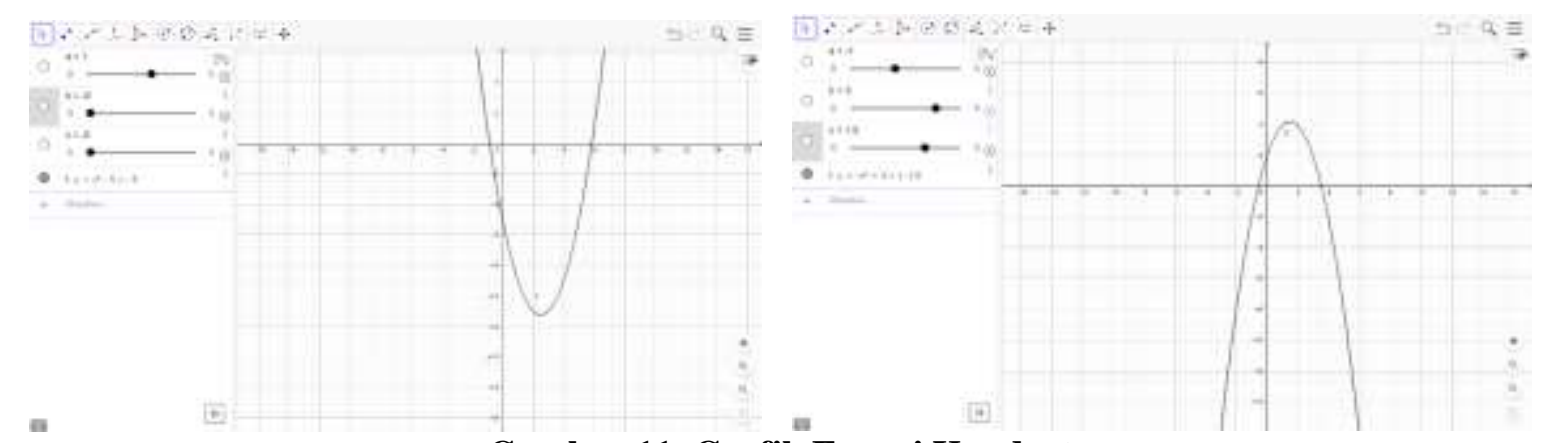

Gambar 11. Grafik Fungsi Kuadrat

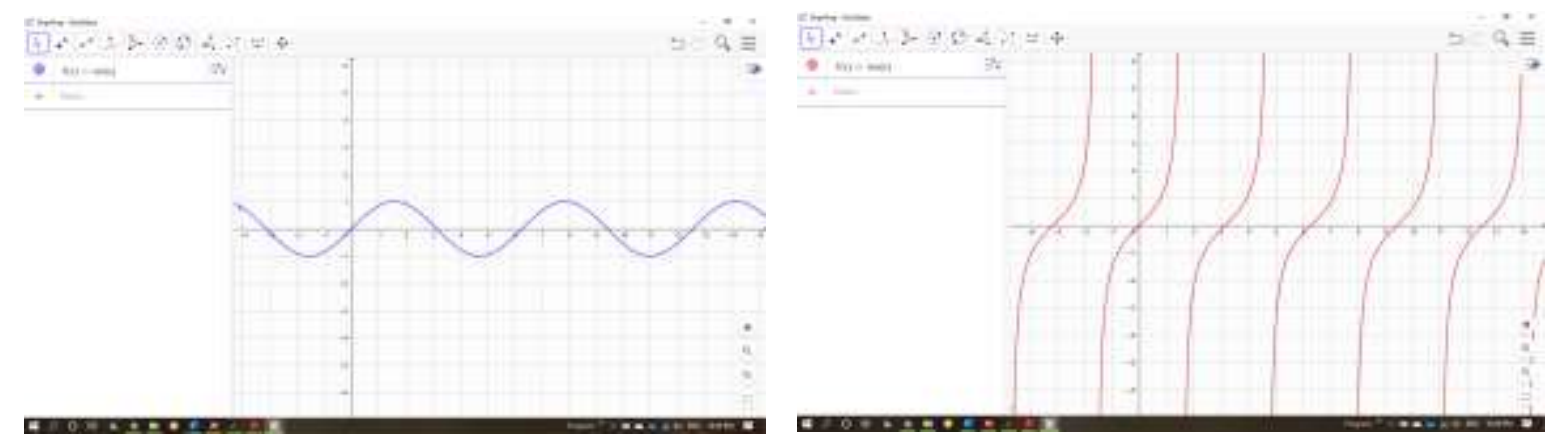

Gambar 12. Grafik Fungsi Sinus dan Fungsi Tangent

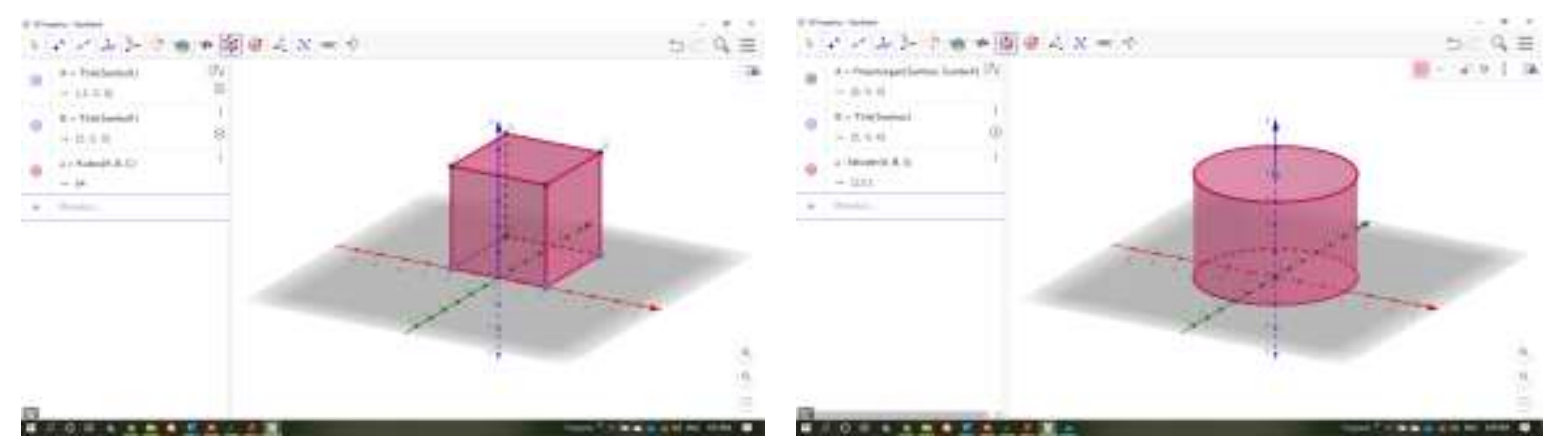

Gambar 13. Kubus dan Tabung 


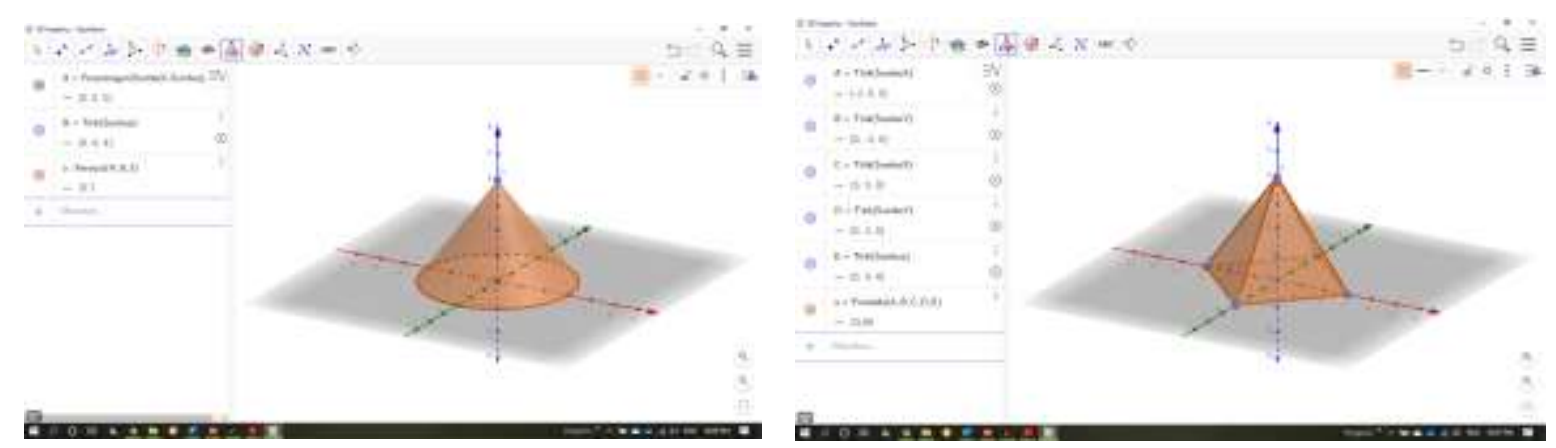

Gambar 14. Kerucut dan Limas

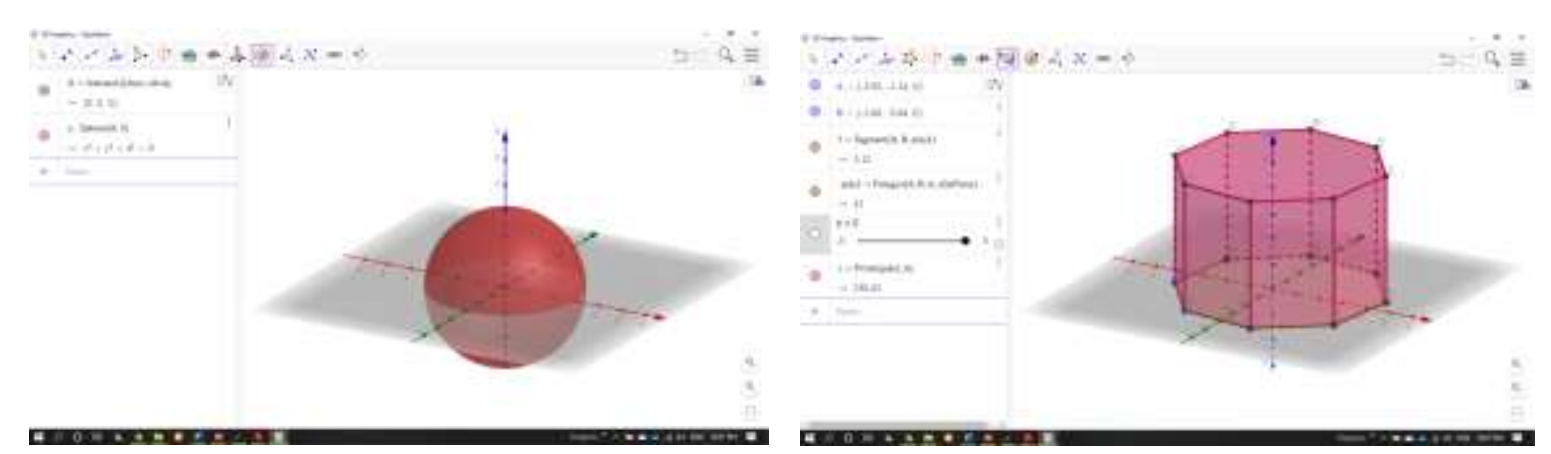

\section{Gambar 15. Bola dan Prisma}

Gambar 10 - 15 menunjukkan penerapan konsep matematika yang dapat dijelaskan dengan bantuan software GeoGebra seperti konsep aljabar antara lain grafik fungsi linier, fungsi kuadrat, fungsi sinus, dan fungsi tangent, dan konsep geometri antara lain bangun ruang kubus, balok, tabung, kerucut, limas bola, dan prisma.

\section{KESIMPULAN}

Kegiatan pengabdian kepada masyarakat ini dilakukan oleh tim yang terdiri dari dua orang dosen Universitas Indraprasta PGRI dan dua orang mahasiswa program studi informatika. Mitra dalam kegiatan pelatihan ini adalah PKBM SMP Daarus Sunnah Cibinong. Dalam pelaksanaan kegiatan ini, tim pelaksana memberikan pelatihan kepada para guru berupa Pelatihan software aplikasi Cabri 3D dan GeoGebra bagi Guru-Guru di sekolah mitra. Kegiatan pelatihan ini memperoleh sambutan positif dari pihak sekolah karena program ini sesuai dengan permasalahan yang sedang dihadapi para guru. Bentuk sambutan positif tersebut dapat dilihat dari keikutsertaan aktif para peserta kegiatan pengabdian masyarakat ini.

Pelatihan tersebut berisi kegiatan pengenalan dan praktik aplikasi Cabri $3 D$ dan GeoGebra. Pada tahap ini, para peserta diberikan penjelasan tentang software Cabri 3D dan GeoGebra kemudian diminta mempraktikkan secara bersama-sama dengan para peserta lainnya. Sebagian besar peserta sudah dapat menjalankan aplikasi Cabri 3D dan Geogebra. Kondisi ini menunjukkan bahwa mereka telah mengalami perkembangan yang luar biasa, sehingga peserta 
pelatihan diperkirakan sudah mampu menjalankan Cabri 3D seperti ini saat melakukan kegiatan belajar mengajar di kelas dan mampu menjalankan menu GeoGebra untuk pembuatan bangun ruang dalam pembelajaran di kelas.

Kegiatan ini belum sepenuhnya mencapai target dan luaran yang diharapkan. Namun, kegiatan ini telah memberikan kontribusi yang posistif bagi guru-guru PKBM SMP Daarus Sunnah Cibinong. Pengaplikasian Cabri 3D dan GeoGebra diharapkan dapat membuat proses belajar mengajar siswa menjadi lebih cepat dan praktis. Dalam pelaksanaan kegiatan ini, diidentifikasi bahwa beberapa guru terkendala dalam GeoGebra karena belum terbiasa dengan penggunaan laptop, khususnya pengoperasiannya. Meski mengalami beberapa kendala, mayoritas guru memberikan respon positif terhadap pelatihan ini. Dari evaluasi yang tim lakukan, disimpulkan bahwa para guru harus sering berlatih mengoperasikan Cabri 3D dan GeoGebra agar terbiasa dengan kedua menu ini.

Dengan adanya pelatihan yang dilakukan, diharapkan para guru dapat mengembangkan proses pembelajaran yang ada di sekolah. Guru dapat menyelesaikan kendala yang dihadapi dalam kegiatan pembelajaran dan guru lebih kreatif dan inovatif dalam melakukan pembelajaran di kelas. Kegiatan pengabdian selanjutnya dapat dilakukan dengan mengalokasikan waktu kegiatan yang jauh lebih lama sehingga guru dapat lebih leluasa dalam praktik kegiatan pengabdian yang dilakukan. Dengan waktu yang lebih lama maka dapat mengeksplorasi semua fitur yang ada dalam software Cabri 3D dan GeoGebra sehingga mampu meningkatkan kreativitas guru dalam membuat media pembelajaran virtual atau bahan ajar untuk pembelajaran di kelasnya.

\section{UCAPAN TERIMA KASIH}

Tim pelaksana kegiatan pengabdian kepada masyarakat mengucapkan terima kasih kepada LPPM Universitas Indraprasta PGRI yang telah menyediakan segala keperluan administrasi dalam pelaksanaan kegiatan ini dan terima kasih kepada mitra kegiatan yaitu PKBM SMP Daarus Sunnah Cibinong yang telah menyediakan kebutuhan dan perlengkapan dalam pelaksanaan kegiatan pengabdian kepada masyarakat ini.

\section{DAFTAR PUSTAKA}

Accascina, G., \& Rogora, E. (2006). Using Cabri 3D Diagrams for Teaching Geometry. The International Journal for Technology in Mathematics Education.

Adirakasiwi, A. G., \& Warmi, A. (2018). Penggunaan Software Cabri 3D dalam Pembelajaran Matematika Upaya Meningkatkan Kemampuan Visualisasi Spasial Matematis Siswa. Jurnal Silogisme, 3(1), 28-35. 
Akhirni, A., \& Mahmudi, A. (2015). Pengaruh Pemanfaatan Cabri 3D dan GeoGebra pada Pembelajaran Geometri Ditinjau dari Hasil Belajar dan Motivasi. Jurnal Pendidikan Matematika Dan Sains, 3(2), 91-100. https://doi.org/10.21831/jpms.v6i2.10922

Anthony, G., \& Walshaw, M. (2009). Characteristics of effective teaching of mathematics: A view from the West. Journal of Mathematics Education, 2(2), 147-164. http://knowledgeportal.pakteachers.org/sites/knowledgeportal.pakteachers.org/files/resou rces/Characteristics of Effective Teaching of Mathematics.pdf

Bustomi, A. Y. (2010). Aplikasi Pembelajaran Panca Indra Pada Manusia Berbasis Android. Jurnal Telematika, 3(1), 25-36.

Ekawati, A. (2016). Penggunaan Software Geogebra Dan Microsoft Mathematic Dalam Pembelaran Matematika. Math Didactic: Jurnal Pendidikan Matematika. https://doi.org/10.33654/math.v2i3.43

Fisher, F. (2017). "Messing Around” In Geogebra: Online Inquiry Through Apps And Games. Proceedings of the 4th Annual Southern Connecticut GeoGebra Conference, 40-47.

Hikmah, R., \& Selvia, N. (2019). Pelatihan Cabri 3d V2 Untuk Menigkatkan Kreativitas Guru Dalam Pembelajaran Bangun Ruang. Jurnal PKM: Pengabdian Kepada Masyarakat, 02(02), 155-161.

Hohenwarter, M., Hohenwarter, J., Kreis, Y., \& Lavicza, Z. (2008). Teaching and learning calculus with free dynamic mathematics software GeoGebra. 11th International Congress on Mathematical Education.

Kristin, N., Anggar, W., \& Rudhito, M. A. (2013). Pemanfaatan Program Cabri 3D Dalam Peningkatan Kemampuan Berpikir Geometri Materi Luas Permukaan Dan Volume Limas Model Pbi Kelas Viii. Seminar Nasional Sains Dan Pendidikan Sains VIII, 4(1).

Mahmudi, A. (2011). Pemanfaatan Program Geogebra dalam Pembelajaran Matematika. Seminar Nasional LPM UNY. https://doi.org/10.1038/oncsis.2016.1

Maulana, I., Saluky, S., \& Misri, M. (2017). Pengaruh Penggunaan Software Cabri 3d Terhadap Minat Dan Hasil Belajar Matematika Pada Pokok Bahasan Bangun Ruang. Information Technology Engineering.

Novianggraeni, T., \& Siswono, T. (2017). Improving Students' Creative Thinking Ability Through Problem Posing-Geogebra Learning Method. MATHEdunesa : Jurnal Ilmiah Pendidikan Matematika, 2(6), 160-166.

Oktaria, M., Alam, A. K., \& Sulistiawati, S. (2016). Penggunaan Media Software GeoGebra untuk Meningkatkan Kemampuan Representasi Matematis Siswa SMP Kelas VIII. Kreano, Jurnal Matematika Kreatif-Inovatif, 7(1), 99-107. https://doi.org/10.15294/kreano.v7i1.5014 
Pranasiwi, O., Iqbal, M., \& Suratno, S. (2015). Pengembangan Aplikasi Kunci Determinasi Berbasis Android Pokok Bahasan Mamalia di SMA / MA ( Application Development of Determination Key Based on Android System Topic Mammals in SMA / MA ). Artikel Ilmiah Mahasiswa, II(1), 1-7.

Rososzczuk, R. (2015). Application Of Cabri 3d In Teaching Stereometry. Advances in Science and Technology Research Journal. https://doi.org/10.12913/22998624/ 2382

Widyastuti, R., \& Nurhamida, F. (2017). Metode Discovery Learning Berbantuan Software Geogebra Untuk Meningkatkan Kemampuan Berfikir Matematis Mahasiswa Politeknik Kediri. Jurnal Mercumatika : Jurnal Penelitian Matematika Dan Pendidikan Matematika, 2(1), 31-39. 